\title{
ANALISIS KEGIATAN MERONCE MENGGUNAKAN TUTUP BOTOL BEKAS TERHADAP KETERAMPILAN MOTORIK HALUS ANAK USIA DINI 5-6 TAHUN
}

\author{
Bahran Taib1, Umikalsum Arfa'2, Hasni Hasbin ${ }^{3}$ \\ Universitas Khairun Ternate \\ Fakultas Keguruan dan Ilmu Pendidikan \\ Jl, Bandara Babullah Kota Ternate Utara, Kode Pos 53 Ternate 97728 \\ Telepon (0921)3110905-faksimili 0921-3110901 \\ Email: taibbahar4685@gmail.com
}

\begin{abstract}
Abstrak: Adapun salah satu kegiatan yang dapat diterapkan dalam pembelajaranpengembangan kemampuan motorik halus yaitu dengankegiatan meronce. Meronce adalah merupakan cara pembuatan benda hias atau benda pakai yang dilakukan dengan menyusun bagian-bagian bahan berlubang atau sengaja dilubangi memakai bantuan benang, tali dan sejenisnya, Penggunaan media meronce dalam kajian ini dengan memanfaatkan berbagai macam tutup botol bekas. Kajian ini bertujuan menganalisis kegiatan meronce terhadap keterampilan motorik halus dan membantu guru dalam penggunaan media pembelajaran khususnya pada kegiatan meronce. Dalam kajian ini penulis menggunakan metode dengan pendekatan studi literatur yangmerupakan penelitian dengan pengumpulan data pustaka, buku-buku, serta artikel atau jurnal yang sudah dipublikasikan terkait dengan judul kajian ini. Selain itu kegiatan meronce menggunakan tutup botol bekas dalam mengembangkan motorik halus, memudahkan anak dalam mengoptimalkan koordinasi mata dan tangan, kecermatan serta kecepatan pada pengembangan keterampilan motorik halus anak usia dini 5-6 tahun.
\end{abstract}

Kata Kunci: Meronce, Keterampilan, Motorik Halus

Abstract: One of the activities for develop the fine motor skills of children aged 5-6 years is meronce. It is a method for make a decoration or use objects by arranging parts of perforated objects using threads/ropes and something like that, the media used in meronce is to use various kinds of used bottle caps. This study aims to analyze the influence of meronce on fine motoric skills and assist teacher in using instructional media.. The research method used is library study. Library study is research by collecting data from books and published articles or journals related to the title of this study. Besides that, meronce using used bottle caps for developing fine motor skills of children could optimize eyes and hands coordination. Accuracy and celerity in developing fine motoric skills of childhood aged 5-6 years.

Keywords: Meronce, Fine Motoric Skills

\section{A. Pendahuluan}

Pendidikan adalah proses interaksi antara pendidik dan anak didik atau lingkungan secara sadar, teratur, terencana dan sistematis guna membantu pengembangan potensi didik secara maksimal, pendidikan anak usia dini (PAUD) adalah pemberian upaya menstimulasi, membimbing, mengasuh dan pemberian kegiatan pembelajaran yang akan menghasilkan kemampuan dan keterampilan pada anak.Salah satu bidang pengembangan kemampuan dasar anak usia dini adalah perkembangan fisik (motorik halus dan kasar) sangat penting bagi kehidupan anak 
usia dini, terutama dalam pengembangan motorik halus pada anak karena merupakan gerak tubuh yang melibatkan kelompok otot dan saraf kecil motorik halus juga merupakan keterampilan menggunakan media dengan koordinasi antara mata dan tangan, pengembangan motorik halus pada anak usia dini, salah satu kegiatan yang dapat dilakukan yaitu dengan kegiatan meronce yang merupakan salah satu pembelajaran di TK yang menarik dan menyenangkan untuk anak.Anak pada usia Kelompok bermain atau usia 5-6 tahun itu seharusnya tahapan kemampuan motorik halus sudah terstimulasi dengan baik, tahapan motorik halus mencakupkemampuan kelenturan menggunakan jari dan alat untuk mengeksplorasi dan mengekspresikan diri dalam berbagai bentuk karya, keterampilan motorik halus penggunaan otot dan saraf kecil yang maksimal, otot-otot tersebut berfungsi untuk melakukan gerakangerakan bagian tubuh yang lebih spesifik, anak pada tahapan mengambil benda dengan jari, memindahkan benda dari satu tangan ke tangan yang lainseperti menulis, melipat, menggunting, meronce.

Melihat dari tahapan kemampuan motorik halus tersebut ada salah satu kegiatan yang dapat mengembangkan kemampuan motorik halus yaitu dengan kegiatan meronce. Keterampilan motorik halus adalah gerakan yang hanya melibatkan bagian-bagian tubuh tertentu saja dan dilakukan oleh otot-otot kecil seperti menggunakan jari-jemari tangan dan gerakan pergelangan tangan. Keterampilan motorik halus tidak terlalu membutuhkan tenaga namun gerakan motorik halus ini membutuhkan koordinasi mata dan tangan yang cermat serta membutuhkan konsentrasi yang baik. Jika motorik halus anak terstimulasi dengan baik maka anak akan dapat berkreasi dengan baik pula dan perkembangan fisik motorik halus anak dapat berkembang secara optimal.

Menurut Haeriah Syamsuddin (Murdiana, 2018) permainan meronce bermanfaat untuk melatih motorik halus anak terutama keterampilan jari-jari tangannya. Semakin terampil anak menggunakan jemarinya maka manfaatnya akan semakin baik terutama saat ia masuk sekolah nantinya. Saat anak harus menulis serta melakukan kegiatan lainnya. Permainan ini juga berguna untuk melatih konsentrasi serta ketelatenan anak. memasukkan satu per satu ronce ke dalam seutas benang memang memerlukan konsentrasi dan ketelatenan. Selain itu daya seni serta kreativitas anak juga terasah. Hal ini bisa dilihat dari aneka jenis ronce yang ia hasilkan. Meronce merupakan cara pembuatan benda hias atau benda pakai yang dilakukan dengan menyusun bagian-bagian bahan berlubang atau yang sengaja dilubangi memakai bantuan benang, tali dan sejenisnya. Kedua kemampuan tersebut sangat penting agar anak bisa berkembang dengan optimal dan dapat mengerjakan tugas-tugas dengan lancar tanpa ada gangguan dalam gerak otot-otot. Oleh sebab itu diharapkan seorang pendidikan yang kreatif agar anak merasa senang, aman, nyaman dan tidak merasa bosan dalam proses belajar mengajar sehingga anak dapat berkembang secara maksimal (Endayanti, 2013). Meronce pada anak usia dini merupakan pembelajran yang sangat menyenangkan bagi anak, selain menyenagkan kegiatan meronce juga untuk melatih ketrampilan motorik halus anak, melatih konsentrasi anak, kecepatan serta melatih kecermatan menggunakan jari jemari dalam kehidupan sehari-hari anak. Kegiatan meronce mudah untuk dipraktekkan kepada anak secara langsung juga dapat menumbuhkan daya kretivitas anak.

Berdasarkan analisis dari kajian ini khususnya pada lembaga pendidikan anak usia dini dalam kegiatan meronce masih jarang dilakukan, salah satu yang menjadi 
penghambat adalah fasilitas sekolah yang terbatas, dan juga guru yang hanya menggunakan media pembelajaran yang monoton seperti menggambar, sehingga tidak menarik perhatian anak dan timbul kebosanan pada anak, tentunya juga menghambat perkembangan motorik halus anak. Oleh karena itu kajian study literatur ini bertujuan menganalisis kegiatan meronce menggunakan tutup botol bekas terhadap keterampilan motorik halus anak usia 5-6 tahun dan berbagi pengetahuan tentang bagaimana mengembangkan aspek motorik khususnya pada pengembangan keterampilan motorik halus dengan media pembelajaran yang di gunakan yaitu meronce menggunakan tutup botol bekas.

Meronce dengan media tutup botol bekas terhadap pengembangan keterampilan motorik halus dengan meningkatkan koordinasi indra mata dan aktivitas tangan, ketepatan serta kecepatan penggunaan otot-otot halus, dan juga dapat mengenalkan pada anak bahwa tutup botol bekas dapat dioleh menjadi barang baru dan dimanfaatkan sebagai alat permainan media belajar. Dengan demikian, dapat dibuktikan bahwa kegiatan meronce dengan media tutup botol bekas dapat memberikan pengaruh yang signifikan terhadap Keterampilan Motorik Halus anak usia 5-6 tahun.

\section{Metode}

Metode yang digunakan dalam penelitian ini dengan pendekatan studi literatur (library reseach).Pendekatan study literatur merupakan penelitian yang serangkaian kegiatannya dengan metode pengumpulan data biasanya berupa catatan yang dipublikasihkan, buku teks, surat kabar, majalah, arikel, serta tulisan yang terkait dengan judul penelitian.

\section{B. Pembahasan}

\section{Pengertian Meronce}

Kegiatan meronce pada anak usia 5-6 tahun di dalam peraturan menteri pendidikan nasional Republik Indonesia nomor 58 Tahun 2009 merupakan bagian dari tingkat pencapaian perkembangan motorik halus yaitu melakukan eksplorasi dengan berbagai media dan kegiatan.Menurut Sumanto meronce merupakan kagiatan yang menyenangkan untuk anak ( Wulandari, 2018), meronce merupakan cara pembuatan benda hias atau benda pakai yang dilakukan dengan menyusun bagian-bagian bahan berlubang atau yang sengaja dilubangi memakai bantuan benang, tali dan sejenisnya". Meronce memiliki makna yang sama dengan kata merangkai (Gusti, 2019). Pendapat lain dikemukan Hajar Pamadhi, dkk. Meronce adalah menata dengan bantuan mengikat komponen dengan utas atau tali. Sri Murtono (Handayani, 2016) juga berpendapat, meronce adalah teknik membuat benda pakai/hias dari bahan manik-manik, biji-bijian, atau bahan lain yang dapat dilubangidengan alat tusuk sehingga dapat dipakai). Jadi kata meronce memiliki hakikat yang sama dengan kata merangkai. Salah satu aspek perkembangan yang mempunyai pengaruh dalam anak belajar yaitu aspek fisik motorik. Menurut Santrock, aspek perkembangan motorik terdapat dua unsur yaitu keterampilan motorik kasar dan keterampilan motorik halus (Awallya, 2018). Jadi kata meronce memiliki hakikat yang sama dengan kata merangkai, pekerjaan yang mencerminkan wujud penghargaan terhadap keindahan benda-benda alam, Pamadhi (Nurbaiti, 2018). Meronce adalah dari bahan manik- manik, biji- bijian, 
atau bahan lain yang dapat dilubangi dengan alat tusuk sehingga dapat dipakai. Meronce adalah salah satu materi yang bisa diberikan pada anak usia dini, bahan meronce dibagi menjadi dua yaitu:

a. Bahan alam ada bermacam-macam bahan alam yang dapat dibuat menjadi hiasan dengan teknik meronce, contoh kulit kerang, dan biji-bijian, batang, buah, serta bebatuan (biji sawo, biji sirkaya, biji jarak, biji kapuk randu).

b. Bahan Buatan Bahan buatan biasanya adalah olahan yang diproduksi dari pabrik dan mudah didapat di toko yang menyediakan benda kerajinan.

Berdasarkan uraian teori diatas penulis menyimpulkan bahwa meronce pada kajian ini menggunakan tutup botol yang merupakan bahan bekas yang di manfaatkan dalam kegiatan meronce dengan cara dengan memasukkan tali/benang kedalam tutup botol bekas sehingga menjadi satu kreativitas yang indah dan djadikan benda hias atau benda pakai dengan membutuhkan keterampilan koordinasi antara tangan dan mata.

\section{a. Tahapan Meronce}

Meronce merupakan tahapan membaca karena ketika sedang meronce anak belajar cara membedakan. Kegiatan membedakan inilah yangdapat melatih kemampuan anak dalam membedakan huruf karena dengan meronce melatih koordinasi mata dan tangan anak. Menurut Dessy Rilia (Endayanti, 2013) kegiatan meronce mempunyai beberapa tahapan dalam aplikasinya yaitu:

1) Meronce berdasarkan warna, tahap ini adalah tahapan yang paling rendah dalam kegiatan meronce. Anak memasukkan benang kedalam lubang berdasarkan warna yang sama, misal warna biru saja.

2) Meronce berdasarkan bentuk, ini salah satu langkah maju yaitu anak dapat mengenal bentuk. Ada berbagai macam bentuk dalam meronce, misalnya bentuk bulat atau kubus.

3) Meronce berdasarkan warna dan bentuk, anak mulai bisa menggabungkan mana yang memiliki bentuk sama dan warna yang sama. Anak mengembangkan kreativitasnya dengan bentuk dan warna yang anak sukai.

4) Meronce berdasarkan warna, bentuk dan ukuran. Tahapan yang cukup sulit bagi anak karena mulai menggabungkan tiga komponen sekaligus.

Dari beberapa tahapan meronce di atas dalam kajian ini meronce dengan berbagai warna tutup botol bekas dengan memberikan kebebasan pada untuk memilih warna yang disukai anak dalam membuat roncean hiasan dinding.

\section{b. Manfaat dan tujuan Meronce}

Untuk anak terdapat banyak manfaat dari meronce, berbagai ahli telah menjelaskan manfaat. Adapun manfaat permainan meronce untuk anak menurut Effiana Yuriastien dkk (Endayanti, 2013) adalah sebagai berikut:

1) Membantu kemampuan motorik halus. Saat anak melalukukan kegiatan meronce anak memasukkannya ke dalam lubang dengan menggunakan tali. 
2) Melatih koordinasi mata dan tangan. Anak menggunakan kedua tangan dan mata untuk memasukkan roncean. Sehingga membutuhkan koordinasi mata dan tangan

3) Meningkatkan perhatian dan konsentrasi. Pada saat anak meronce, anak membutuhkan latihan dan konsentrasi saat memasukkan roncean ke dalam lubang dengan tepat.

Adapun tujuan meronce pada anak usia dini sebagai berikut

1) Permainan, merangkai maupun meronce berfungsi sebagai alat bermain anak, benda-benda yang akan dirangkai tidak ditujukan untuk kebutuhan tertentu melainkan untuk latihan memperoleh kepuasan rasa dan memahami keindahan. Hal ini sesuai dengan karakteristik seorang anak bahwa pada setiap saat benda itu digunakan sebagai alat bermain sehingga merangkai adalah salah satu jenis bermain.

2) Kreasi dan komposisi, kemungkinan benda atau komponen lain dapat diminta guru kepada anak untuk menyusun ala kadarnya. Benda-benda tersebut dikumpulkan dari lingkungan sekitar, seperti: papan bekas, atau kotak sabun serta yang lain dibayangkan sebagai bangun yang megah. Anak sengaja hanya bermain imajinasi saja, sehingga tujuan permainan ini untuk melatih imajinasi atau bayangan anak tentang intruksi suatu bangun.

3) Gubahan atau inovasi, merangkai dan meronce dapat ditujukan untuk melatih kreativitas, yaitu dengan cara mengubah fungsi lama menjadi fungsi baru. Berdasarkan uraian diatas dapat diambil kesimpulan bahwa meronce dapat memberikan ksempatan anak dalam berkarya juga dapat difariasikan dan dibentuk menurut keinginan sehingga anak tertarik dan terlatih untuk menciptakan ide baru, dengan kegiatan meronce anak akan merasakan dan mendapatkan pengalaman langsung serta terampil untuk melakukan kegiatan yang menggunkan kemampuan motorik halus dan lainnya (Fitrianingsih dan Karmila, 2013)

Dari bebrapa manfaat diatas penulis menyimpulkan bahwa manfaat kegiatan meronce dalam kajian ini yaitu mengembangkan keterampilan motorik halus, melatih koordinasi mata dan tangan yang membutuhkan konsentrasi anak, dan juga dapat dimanfaatkan oleh guru sebagai baham pembelajaran untuk anak usia dini 5-6 tahun

Ada berbagai macam tujuan dari meronce, adapun tujuan meronce menurut Hajar Pamadhi (Endayanti, 2013) yaitu:

1) Permainan merangkai maupun meronce berfungsi sebagai alat bermain anak, benda-benda yang akan dirangkai tidak ditujukan untuk kebutuhan tertentu melainkan untuk latihan memperoleh kepuasan rasa dan memahami keindahan. Hal ini sesuai dengan karakteristik seorang anak bahwa pada setiap saat benda itu digunakan sebagai alat bermain sehingga merangkai adalah salah satu jenis bermain.

2) Kreasi dan komposisi kemungkinan benda atau komponen lain dapat diminta guru kepada anak untuk menyusun ala kadarnya. Benda-benda tersebut dikumpulkan dari lingkungan sekitar, seperti: papan bekas, atau kotak sabun serta yang lain dibayangkan sebagai bangunan yang megah. Anak sengaja hanya bermain imajinasi saja, sehingga tujuan permainan ini untuk melatih imajinasi atau bayangan anak tentang intruksi suatu bangun. 
3) Perubahan atau inovasi merangkai dan meronce dapat ditujukan untuk melatih kreativitas, yaitu dengan cara mengubah fungsi lama menjadi fungsi baru. Kegiatan dapat dilakukan dengan merubah kegiatan anak misalnya anak sudah bisa meronce berdasarkan bentuk kemudian guru dapat meminta anak meronce ke tahapan yang lebih sulit yaitu meronce berdasarkan bentuk dan warna.

Berdasarkan uraian diatas penulis dapat menyimpulkan bahwa kegiatan meronce dengan menggunakan tutup botol bekas dapat melatih koordinasi mata dan tangan selain itu dengan kegiatan meronce anak akan mendapatkan pengalaman secara langsung dalam berkretivitas, melatih konsentrasi, serta terampil menggunakan jari jemari tangan. Kegiatan meronce menggunakan tutup botol bekas dalam kajian ini sangat sederhana dan cukup mudah untuk dipraktekkan dengan kegiatan meronce menggunakan tutup botol bekas dapat menarik minat dan perhatian anak sehingga terjalin interaksi yang baik antara guru dan anak.

\section{Keterampilan Motorik Halus}

\section{a. Pengertian Keterampilan Motorik Halus}

Keterampilan motorik halus melibatkan gerakan yang diatur secara halus, menggenggam mainan, mengancing baju, atau melakukan apapun yang memerlukan keterampilan tangan menunjukkan Keterampilan motorik halus, saat anak berumur 5-6 tahun koordinasi motorik halus anak semakin meningkat seperti tangan, lengan, dan jari semua bergerak bersama di bawa perintah mata (Shantrock, 2007).

Pengunaan tangan untuk memindahkan objek secara tepat dan akurat adalah tugas yang disebut sebagai keterampilan motorik halus seperti melibatkan kegiatan menjahit lurus, memotong objek dengan lumayan bagus dengan gunting, dan memasukkan benang ke dalam manik-manik secara independen (Hasnida, 2016). Motorik halus adalah perkembangan gerak fisik seorang individu yang meliputi otot kecil serta koordinasi seimbang antara mata dan tangan (Risaldy, 2015). Adapun perkembangan motorik halus adalah meningkatkkan pengoordinasian gerak tubuh yang melibatkan otot dan saraf yang lebih kecil (fahkrauddin, 2018).

Berdasarkan teori diatas penulis menyimpulkan bahwa keterampilan motorik adalah kegiatan yang berhubungan dengan jari-jemari tangan yang dengan koordinasi antara tangan dan mata yang sangat membutuhkan konsentrasi dalam melakukannya.

Suyandi mengutip pendapat Laura E. Berk mengungkapkan bahwa gerak motorik halus adalah meningkatnya pengkoordinasian gerak tubuh yang melibatan kelompok otot dan saraf kecil lainnya. Sedangkan menurut Janet W. Lenner, gerak motorik halus merupakan keterampilan menggunakan media dengan koordinasi antara mata dan tangan. Kemampuan motorik halus tangan mengembangkan kemampuan anak dalam menggunakan jari-jarinya, khususnya ibu jari dan jari telunjuk (Wiyani 2015), kemampuan ini di antara lain: 
1) Menggenggam (grasping), kemampuan menggenggam pada anak meliputi palmer grasping dan pincer grasping, Palmer Grasping adalah Anak menggenggam suatu benda dengan menggunakan telapak tangannya, biasanya anak yang berusia dibawah 1,5-2 tahun lebih cenderung menggunakan genggaman ini. Anak merasa lebih mudah dan sedarhanadengan memegang benda menggunakan telapak tangan. Sedangkan Pincer grasping adalah Perkembangan motorik halus yang semakin baik akan mendorong anak untuk dapat memegang tidak dengan telapak tangan lagi tetapi dengan menggunakan jari-jarinya(mejempit) pada masa ini anak sudah dapat diajari untuk makan menggunakan tangannya dan juga memegang krayon maupun pensil dengan jarinya.

2) Memegang, anak usia dini dapat memegang benda-benda besar maupun benda kecil. Hal ini dikarenakan, semakin tinggi kemampuan motorik halus anak, maka semakin mampuh memegang benda-benda yang kecil.

3) Merobek, keterampilan merobek dapat dilakukan dengan menggunakan tangan sepenuhnya maupun menggunakan dua jari (ibu jari dan telunjuk).

Pada dasarnya setiap aktivitas yang dilakuan oleh anak usia dini melibatkan koordinasi tangan dan mata juga gerakan motorik kasar dan halus. Semakin banyak gerakan yang dilakukan anak, maka makin banyak pula koordinasi yang diperlukannya (Wiyani, 2015).

Berdasarkan uraian diatas penulis menyimpulkan bahwa kemampuan motorik halus tergantung pada gerakan-gerakan jari jemari tangan yang dapat di stimulasi, kegiatan meronce sangat berguna untuk kegiatan belajar mengajar dalam mengembangkan keterampilan motorik halus anak, melatih serta meningkatkan koordinasiindra mata dan aktivitas tangan.

\section{b. Tujuan dan fungsi motorik halus}

Dalam standar kompetensi kurikulum TK tercantum bahwa tujuan pendidikan di TK adalah membantu mengembangkan berbagai potensi anak baik psikis, fisik yang meliputi moral dan nilai-nilai agama, social emosional, kognitif, bahasa, fisik/motorik, kemandirian, dan seni untuk memasuki pendidikan dasar. Sedangkan kompetensi motorik halus anak yang dapat dikembangkan guru pada saat anak memsuki lembaga prasekokolah/TK adalah anak mampu:

1) Melakukan aktivitas fisik secara terkoordinasi dalam rangka kelenturan dan persiapan untuk menulis, keseimbangan, kelincahan, dan melatih keberanian.

2) Mengekspresikan diri dan berkreasi berbagai gagasan dan imajinasi dan menggunakan berbagai media/bahan menjadi suatu karya seni.

Kompetensi anak Tk yang diharapkan dapat dikembangkan guru saat anak memasuki lembaga prasekolah/TK adalah anak mampu melakukan aktivitas motorik secara terkoordinasi dalam rangka kelenturan dan kesiapan untuk menulis, keseimbangan, dan melatih keberanian. Fungsi pengembangan motorik halus pada anak TK sebagai berikut:

1) Melatih kelenturan dan koordinasi otot jari dan tangan.

2) Memacu pertumbuhan dan pengembangan fisik/motorik, rohani dan kesehatan anak. 
3) Membentuk, membangun, dan memperkuat tubuh anak.

4) Melatih keterampilan/ketangkasan gerak dan berpikir anak.

5) Meningkatkan perkembangan emosional anak.

6) Meningkatkan perkembangan sosial anak.

7) Menumbuhkan perasaan menyukai dan memahami manfaat kesehatan pribadi (Rosidah, 2018).

Kompetensi anak TK yang diharapkan dapat dikembangkan saat anak memasuki lembaga prasekolah/TK adalah anak mampu melakukan aktivitas motorik secara terkoordinasi dalam rangka kelenturan dan kesiapan untuk menulis, keseimbangan, dan melatih keberanian. Adapun tujuan dan fungsi motorik halus menurut Sumantri (Endayanti, 2013) merupakan penguasaan keterampilan yang tergambar dalam kemampuan menyelesaikan tugas motorik tertentu. Kualitas motorik halus terlihat dari seberapa jauh dengan tingkat keberhasilan motorik yang dilakukan seefisien mungkin. Pada perkembangan motorik halus perlu dilskuksn sejak anak usia dini, karena pada masa ini merupakan masa paling ideal dalam mempelajari motorik halus anak, tujuan dan fungsi motorik halus anak sebagai berikut:

1) Mampu mengembangkan kemampuan motorik halus yang berhubungan dengan keterampilan gerak kedua tangan.

2) Mampu menggerakkan anggota tubuh yang berhubungan dengan gerak jari jemari: seperti kesiapan menulis, menggambar dan memanipulasi bendabenda.

3) Mampu mengkoordinasikan indra mata dan aktivitas tangan.

4) Mampu mengendalikan emosi dalam beraktivitas motorik halus.

5) Menunjukkan kemampuan menggerakkan anggota tubuhnya terutama terjadinya koordinasi mata dan tangan sebagai persiapan untuk pengenalan menulis.

Dari uraian di atas dapat disimpulkan bahwa tujuan dan fungsi motorik halus anak sangat penting dalam kehidupan sehari-hari. Pada kemampuan motorik halus dapat dilihat sesuai dengan tahapan usianya sehingga guru bisa mendesain pembelajaran seperti apa yang tepat digunakan dalam meningkatkan motorik halus anak, motorik halus anak perlu mendapatkan stimulasi atau rangsangan agar dapat berkembangan dengan baik.

Berdasarkan penelitian relevan yang telah di lakukan tentang kegiatan meronce dalam mengembangkan keterampilan fisik motorik halus pada anak usia dini, penelitian yang telah dilakukan oleh Mumpuni Arum Bakti dengan judul penelitian peningkatanketerampilan motorik halus melalui kegiatan meronce menggunakan bahan tanah liatkelompok B TK Yayasan Masyithoh Beran Bugel Kulon Progo 2014. Pada siklus I hasil penelitian menunjuk terjadi peningkatan kemampuan motorik halus anak berkembang dengan kreteria sangat baik 7 orang anak (81\%-100\%), berkembang dengan kreteria baik 7 orang anak (61\%-80\%) dan berkembang dengan kreteria cukup 1 orang anak (41\%-60 \%) dengan presentase 76,67\%. Dan peneliti melanjutkan pada siklus II hasil tindakan Siklus II mengalami peningkatan, ada sebanyak 15 anak atau semua anak mendapat kriteria sangat baik dengan memperoleh presentase 94,44\%. Dapat disimpulkan bahwa kegiatan meronce menggunakan bahan 
tanah liat dapat meningkatkan keterampilan motorik halus pada anak B TK Yayasan Masyithoh Beran Bugel Kulon Progo.

Terdapat juga penelitian yang hampir mirip lakukan oleh Nihayaturrohmah dengan judul penelitian implementasi kegiatan meronce dengan bahan bekas dalam mengoptimalkan keterampilan motorik halus pada anak usia dini TK Ngebean I Temple Sleman 2019, hasil dalam proses kegiatan meronce dalam mengoptimalkan keterampilan motorik halus yang akan dicapai anak usia dini menunjukkan bahwa sebagian besar peserta didik dikelas A TK ABA Ngabean sudah mencapai kemampuan keterampilan motorik halus sesuai dengan target yang telah ditentukan salah satunya melakukan kegiatan meronce. Dari 16 orang anak, anak dengan kreteria berkembang sesuai harapan ada 12 orang anak, dan dengan kreteria berkembang sangat baik ada 4 orang anak. Jadi dapat peneliti simpulkan bahwa kegiatan meronce dengan bahan bekas dalam mengoptimalkan keterampilan motorik halus pada kelompok A TK Aba Ngebean telah berhasil.

Penelitian yang sama juga dilakukan oleh Erna Kusnita dengan judul meningkatkan kemampuan motorik halus anak melalui kegiatan meronce dengan media manik-manik di kelompok B TK Aisyiyah Bustanul Athfal Bromo Medan 2017, peneliti melanjutkan pada siklus II menunjukkan bahwa ada peningkatan yaitu anak dengan kreteria mulai berkembang ada 1 orang anak, anak dengan kreteria berkembang sesuai harapan ada 9 orang anak, dan anak dengan kreteria berkembang sangat baik ada 5 . Hal ini dapat dilihat dari kemampuan anak pada siklus I yang mencapai $43 \%$ dan pada siklus II yang mencapai 88\%. Artinya tingkat perkembangan fisik motorik halus anak mengalami kemajuan. Bahwa kemampuan dalam keterampilan menggunakan jari jemari dengan kriteria Berkembang Sesuai Harapan dan Berkembang Sangat Baik keberhasilannya telah mencapai 87\%, bereksplorasi dengan berbagai media keberhasilannya 93\%, koordinasi tangan dengan mata keberhasilannya mencapai $87 \%$, dalam Ketelitian anak dalam bekerja keberhasilannya $80 \%$, serta dalam melatih otot-otot tangan dan jari keberhasilannya telah mencapai $87 \%$. Jadi secara keseluruhan pelaksanaan perbaikan pada siklus II telah berhasil dengan perolehan keberhasilan anak didik mencapai $88 \%$.

Berikutnya juga penelitian relevan yang dilakukan oleh Lela Lavita Amurwaningsih dan Nor Izatil Hasanah dengan judul penelitian pengaruh meronce dengan media tutup botol bekas terhadap keterampilan motorik halus anak kelompok B PAUD Terpadu Ar-Rahmah Kertak Hanyar Kabupaten Banja tahun 2018, hasil tersebut menunjukkan bahwa nilai rata-rata kelas eksperimen 78,66 yang berada pada kualifikasi baik. Kualifikasi ini lebih tinggi dibandingkan dengan nilai rata-rata kelas eksperimen pada saat pre test sebesar 58,28 yang berada pada kualifikasi cukup baik. Dengan demikian, dapat dibuktikan bahwa dengan meronce dengan media tutup botol bekas dapat memberikan pengaruh yang signifikan terhadap Keterampilan Motorik Halus anak kelompok B PAUD Terpadu Ar-Rahmah.

Kemudia penelitian relevan yang dilakukan oleh Riski Oktavianita Lestari dan Muniroh Munawar dengan judul penelitian upaya meningkatkan motorik halus anak melalui kegiatan meronce menggunakan media limbah 
kertas pada kelompok A di RA Taqwalilah Semarang tahun pelajaran 2015/2016, pada siklus I dengan presentase hasil belajar anak 46,66\% sehingga dapat dikatakan ada peningkatan sebesar 33,33\% pada siklus I. Pada siklus II presentase hasil belajar anak meningkat sebesar $40 \%$ menjadi 86,66\%. Penelitian ini dapat disimpulkan bahwa melalui kegiatan meronce menggunakan media limbah kertas dapat meningkatkan motorik halus anak pada Kelompok A RA Taqwal Ilah Semarang.

Penelitian relevan selanjutnya yang dilakukan oleh Anik Tri Rahayu dengan judul penelitian peningkatan kemampuan motorik halus melalui kegiatan meronce bahan alam pada anak kelompok B TK PKK Selodono Tahun Pelajaran 2015/2016. Berdasarkan hasil observasi penelitian pada RPPH, didapatkan data anak yang menunjukkan bahwa masih rendahnya kemampuan motorik halus pada anak kelompok B, dibuktikan dengan adanya penilaian yang menunjukkan bahwa sebanyak 11 anak mendapat bintang 2, dan 15 anak mendapat bintang 1 . Dari data yang diperoleh dari siklus I adalah sebanyak 27\% dari 26 anak memenuhi kriteria ketuntasan sedangkan 73\% dari 26 anak belum memenuhi ketuntasan karena masih mendapat bintang I dan 2. Pada siklus II sebanyak 58\% dari 26 anak memenuhi kriteria ketuntasan sedangkan $42 \%$ dari 26 anak belum memenuhi kriteria ketuntasan, dan pada siklus III sebanyak 88\% dari 26 anak memenuhi kriteria ketuntasan sedangkan $12 \%$ dari 26 anak belum memenuhi kriteria ketuntasan dan masih memerlukan dampingan atau bantuan dari guru, Sejak pengamatan siklus I sampai siklus III terdapat penjelasan tentang perkembangan menuju ke arah positif mengenai perkembangan motorik halus melalui kegiatan meronce bahan alam.

Berdasarkan berbagai jenis penelitian relevan di atas penulis menyimpulkan bahwa observasi awal sebelum penerapan kegiatan meronce yang dilakukan oleh beberapa penelitian rata-rata motorik halus anak belum berkembang, dan pada saat sesudah penerapan kegiatan meronce pada siklus I dan siklus II menunjukkan hasil yang sangat memuaskan atau rata-rata pada kategori berkembang sesuai harapan dan berkembang sangat baik, hal ini menunjukkan bahwa kegiatan meronce dengan media tutup botol bekas dapat meningkatkan keterampilan motorik halus anak usia 5-6 tahun. Gambar kegiatan meronce berikut:

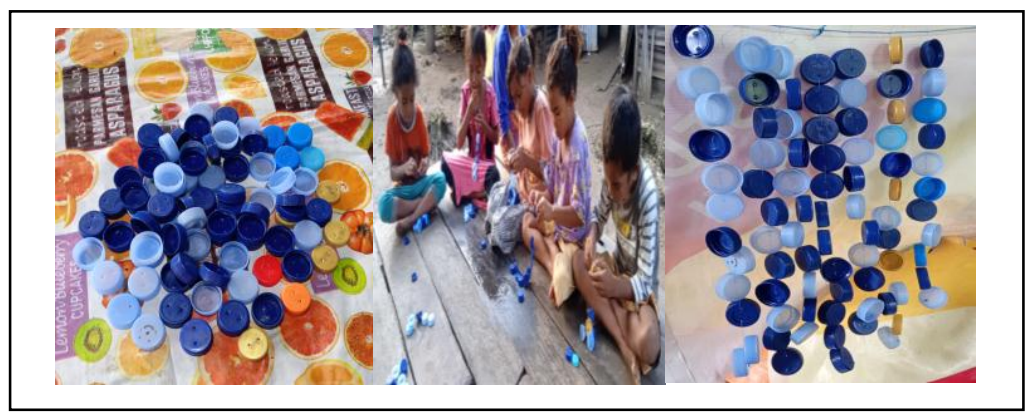

Gambar 1.Langkah-langkah meronce menggunakan tutup botol 
Proses kegiatan meronce menggunakan tutup botol bekas pada gambar diatas penulis mempraktekkan pada anak usia dini 5-6 tahun di Desa Kurunga Kecematan Kepulauan Jouronga Kabupaten Halmahera selatan (Bacan), pada saat sebelum kegiatan penulis menyiapkan bahan tutup botol bekas yang sudah dilubangi dan tali untuk kegiatan meronce, kemudian membagikan kepada anak dan memberikan arahan atau aturan main, setelah itu anak-anak memulai kegiatan meronce, terlihat anak-anak sangat antusias dan konsentrasi saat melakukan kegiatan meronce, rata-rata anak sudah mampu sesuai indikator yang penulis harapkan yaitu mengambil benda dengan jari jemari, memasukkan tali/benang dengan baik, menyelesaikan kegiatan dengan tepat waktu, bahkan anak-anak dengan semangat sehingga anak-anak berinsiatif untuk menjadikan kegiatan meronce sebagai perlombaan dalam menghabiskan roncean, ada satu anak yang terlebih dahulu selesai, setelah ronceannya selesai dia membantu atau memberi arahan kepada temannya yang berada disampingnya dan anak-anak yang lain juga menyelesaikan kegiatan meronce dengan baik. Ada anak yang mengikuti sesuai arahan dalam kegiatan meronce dan juga ada anak yang berinsiatif membuat roncean yang berbeda dalam menyusun tutup botol bekas,

Dari hasil kegiatan meronce penulis dapat menyimpul bahwa kegiatan meronce menggunakan tutup botol bekas dapat mengembangkan

\section{Simpulan} keterampilan motorik halus anak usia dini 5-6 tahun.

Penulis dapat menyimpulkan bahwa kegiatan meronce tersebut dapat mengembangkan keterampilan motorik halus, yang dapat dilihat dari bebrapa penelitian relevan dan hasil dari kajian penulis diatas kegiatan meronce dapat membantu kemampuan motorik halus, melatih serta meningkatkan koordinasi indra mata dan aktivitas tangan, meningkatkan perhatian dan konsentrasi, meningkatkan kemampuan anak seperti ketepatan dan kecepatan. Sehingga, dapat disimpulkan bahwa terdapat pengaruh meronce dengan media tutup botol bekas terhadap keterampilan motorik halus anak usia dini 5-6 tahun.

\section{DAFTAR PUSTAKA}

Amurwaningsih Lela Lavita \& Hasanah Nor Izatil. 2018. Pengaruh Meronce Dengan Media Tutup Botol Bekas Terhadap Keterampilan Motorik Halus Anak Kelompok B Paud Terpadu Ar-RahmahKertak Hanyar Kabupaten Banja. (Diakses pada tanggal 6 juli 2020).

Bakti Arum Mumpuni. 2014. Peningkatan Keterampilan Motorik Halus Melalui Kegiatan Meronce Menggunakan Bahan Tanah Liat Kelompok B Tk Yayasan Masyithoh Beran Bugel Kulon Progo. (Diakses pada tanggal 28 April 2020).

Endayanti, S. 2013. Meningkatkan Kemampuan Motorik Halus Melalui Kegiatan Meronce Pada Anak Kelompok B Masjid Syuhada. Skripsi Universitas Yogyakarta.

Fahkruddin, Umar, A. 2018. Sukses Menjadi Guru Paud. Bandung: PT Remaja Rosdakarya 
Fitrianingsih Dwi \& Mila Karmila . 2013. Upaya Meningkatan Konsentrasi Melalui Kegiatan Meronce Pada Anak Kelompok B Tk Pamekar Budi Kecamatan Mranggen Kabupaten Demak.(Diakses pada tanggal 22 April 2020).

Gusti Ayu Mulyawartini 2019. Melalui Kegiatan Meronce Bentuk danWarna Dapat Meningkatkan Kemampuan Motorik Halus Anak Pada Kelompok B TK Harapan Melayu, Jurnal vol 1 nomor 1 Agustus 2019. (Diakses pada tanggal 22 April 2020)

Handayani. 2016, Keterampilan Meronce Anak Kelompok B TK Gugus 2 Kecematan Kokap. Skripsi Juni 2016. (Diakses pada tanggal 28 April 2020).

Kusnita Erna. 2017. Meningkatkan Kemampuan Motorik Halus Anak Melalui Kegiatan Meronce Dengan Media Manik-Manik Di Kelompok B Tk Aisyiyah Bustanul Athfal Bromo Medan. Jurnavolume 7 no. 1 juni 2017. (Diakses pada tanggal 6 juli 2020).

Nihayaturrohmah. 2019. Implementasi Kegiatan Meronce Dengan Bahan Bekas Dalam Mengoptimalkan Keterampilan Motorik Halus Pada Anak Usia Dini Di TAba Ngabean 1 Tempel Sleman. Skripsi Universitas Islam Negeri Sunan Kalijaga Yogyakarta 2019. (Diakses tanggal 22 april 2020).

Nurbaiti. 2018. Mengembangkan Kemampuan Motorki Halus Melalui Kegiatan Meronce Dengan Bahan Alam Pada Anak Kelompok A TK Dharma Wanita 03 Padangan Kecematan Ngantru Kabupaten Tulung Agung. Skiripsi. Universitas Nusantara PGRI Kediri 2017. (Diakses pada tanggal 28 April 2020).

Murdiana Fitria. 2018. Proses mengembangkan keterampilan motorik halus anak usia dini di Tk SBM Insan Globalisasi Lampun.Skipsi Universitas Ilam Negeri Raden Intan Lampung 2018.(Diakses pada 28 april 2020).

Pamadhi Hajar, dan Sukardi S. 2014. Seni Keterampilan Anak. Tangerang: Universitas Terbuka

Putri SeptianAwallya. 2018. Mengembangkan MotorikHalus Anak Melalui Pemanfaatan Media Bahan Bekas Koran di TK Kartika Fajar Baru Jati Agung Lampung Selatan,skripsi, Universitas Negeri Yogyakarta 2018. (Diakses pada tanggal 22 april 2020).

Rosida. 2017. Skripsi Pengembangan Fisik Motorik Halus Melalui Kegiatan Meronce Dengan Media Tutup Botol B Hias di Kelompok A Ba Aisyiyah Repaking Kecamatan Wonosegoro Kabupaten Boyololi. Skripsi Institut Agama Islam Negeri2018. (Diakses pada tanggal 28 April 2020).

Rahayu Tri Anik. 2015. Peningkatan Kemampuan Motorik Halus Melalui Kegiatan Meronce Bahan Alam Pada Anak Kelompok B TK PKK Selodono. Universitas Nusantara PGRI Kediri 2015. (Diakses pada tanggal 6 juli 2020).

Risaldy, Sibil 2015. Manejemen Penggelolaan Sekolah Dini. Jakarta timur: PT Luxima Metro Media. 
Shantrock, Jhon, A. 2007. Perkembangan Anak. Erlangga: PT Gelora Aksara Pratama

Wiyani, A, Novan. 2015. Manajemen Paud Bermutu. Yogyakarta: Gava Media

Wulandari. 2018. Penerapan Metode Demonstrasi Melalui Kegiatan Meronce Untuk Meningkatkan Perkembangan Motorik Halus Pada Anak Kelompok B1 Kartika VII-3 Singaraja Jurnal Ilmiah Pendidikan Profesi Guru Vol. 1 No. 3, Oktober 2018. (Diakses pada tanggal 28 april 2020 